\title{
Employability of Post Graduate Scholars Studying in VNMKV, Parbhani, India
}

\author{
Kh. Pusparani Devi", J.V. Ekale and M.V. Kulkarni \\ Department of Extension Education, Vasantraoi Naik Marathwada Krishi Vidyapeeth, \\ Parbhani (M.S.), India \\ *Corresponding author
}

\section{A B S T R A C T}

Keywords

Employability, Post graduate, Scholars

Article Info

Accepted:

22 October 2019

Available Online:

10 November 2019
Employability refers to a person's capability of gaining initial employment, maintaining employment and obtaining new employment if required. For individuals, employability depends on the knowledge, skills and abilities they possess, the way they use those assets and present them to the employers and the context in which they seek work. The present study was conducted in three agricultural colleges of VNMKV, Parbhani, Maharashtra, with an objective to find out the employability of post graduate scholars studying in VNMKV, Parbhani. The respondents were selected from each college by proportionate random sampling to comprise a sample of 120 respondents. The method of expost-facto medium research design was adopted for this study. In this research, to study and measure the employability of postgraduate scholars, eleven indicators based on the opinion of experts and review of literature was collected. The statistical measures such as frequency, percentage, arithmetic mean and co-efficient of correlation were used in the study. Majority (86.67\%) of the postgraduate scholars associated with employability had average to high level of overall employability.

\section{Introduction}

Being employable is especially relevant to post graduate scholars at the brink of their careers. Yorke (2006) accordingly defines employability as the skills, understandings and personal attributes that make graduates more to obtain employment and be successful in their occupation to their own advantage, but also to the advantage of the labour force, the community and the economy.

Employability refers to a person's capability of gaining initial employment, maintaining employment and obtaining new employment if required (Hillage and Pollard, 1998). In simple 
terms employability is about capability of getting and keeping fulfilling work. More comprehensively, employability is the capability to move self-sufficient within the labour market to realize potential through sustainable employment. For individuals, employability depends on the knowledge, skills and abilities they possess, the way they use those assets and present them to the employers and the context in which they seek work. Employability is not just about vocational and academic skills. Individuals need relevant and usable labour market information available to them. The factors that help people to be employable include the knowledge and abilities relating to a particular job, the ability to identify suitable job opportunities, self-presentation on applications and interviews and external factors such as the job market and personal circumstances (Sasidharan, 2013).

Technically qualified manpower provided the base for the radical metamorphosis of agriculture - what William Doug of USA called Green Revolution. Right since independence, the country laid maximum emphasis on the development of its human resource through education. In support of that slowly and steadily a comprehensive system of higher agricultural education has been evolved and developed.

The agricultural graduate and postgraduates should be enabled with some marketable professional abilities and employability skills to be successful and economic unit in the competitive technology driven world. Those specific attributes and skills that enable effective and wise use of knowledge, experience and formal education includes written communication viz., ability to express clearly in writing, verbal communication like expressing ideas clearly and confidently in speech, critical thinking skills, flexibility to successfully adapt changing situations and environment persuading ability to convince others to discuss and reach agreement, teamwork for working confidently within a group, leadership quality to be able to motivate and direct others, planning and organizing capacity to be capable to plan activities and carry them through effectively, investigating, analysing and problem solving aptitude for gathering information systematically to establish facts and principles, numeracy to carry out arithmetic operations/understand data and computing skills as well as developing professionalism. Value and ethics like honesty and personal quality like responsibility, self-confidence and self-reliance are also very much essential for developing the employability for agricultural graduates. Considering this, the present investigation was conducted "Employability of post graduate scholars studying in VNMKV, Parbhani”.

\section{Materials and Methods}

The study was undertaken using proportionate random sampling of postgraduate research scholars studying in $2^{\text {nd }}$ year at College of Agriculture, Parbhani, College of Agriculture, Latur and College of Agriculture, Badnapur. The basic information regarding the postgraduate research scholars was collected from the PG Branch of VNMKV, Parbhani.

The data was collected using structured interview schedule and some scales developed by different scientists with slight modification and collected data was analysed using frequency, percentage, mean, standard deviation and class interval. The present study was conducted applying ex-post-facto research design.

To know the overall employability of the respondents, eleven indicators were selected and the weight age scores of these indicators were worked out on the basis of an extensive 
review of literature on the subjects and previous studies taken up on the related subjects. The selected indicators were Fundamental employability aptitude, General knowledge about agriculture, Knowledge about current issues, Knowledge about Government policies on agriculture, Communication skills, Information Communication Technology skills, Ability to face interviews, Self confidence, Competition orientation, Habit of information collection, Attitude towards agriculture education

To find out the overall employability index, the following formula was used.

Overall Employability Index $=\left(\mathrm{R}_{1} / \mathrm{M}_{1}\right) \times \mathrm{W}_{1}$ $+\left(\mathrm{R}_{2} / \mathrm{M}_{2}\right) \times \mathrm{W}_{2}+\ldots+\left(\mathrm{R}_{\mathrm{n}} / \mathrm{M}_{\mathrm{n}}\right) \times \mathrm{W}_{\mathrm{n}}$

Where,

$R_{1}, R_{2} \ldots \ldots \quad R_{n}=$ Received score for each indicator by each respondent

$\mathrm{M}_{1}, \mathrm{M}_{2} \ldots \ldots \mathrm{M}_{\mathrm{n}}=$ Maximum score one can get for each indicator

$\mathrm{W}_{1}, \mathrm{~W}_{2} \ldots \mathrm{W}_{\mathrm{n}}=\mathrm{Weightage}$ score of each indicator received from experts

\section{Objectives}

To find out the employability of post graduate scholars studying in VNMKV, Parbhani

\section{Results and Discussion}

To know the overall employability of the respondents, eleven indicators were selected. The results obtained are given in Table 1. It is obvious from Table 1 that 62.50 per cent of the postgraduate scholars studying in VNMKV, Parbhani had medium level of fundamental employability aptitude, followed by 19.17 per cent and 18.33 per cent with low and high level of fundamental employability aptitude, respectively. It is evident that more than half (58.33 per cent) of the postgraduate scholars studying in VNMKV, Parbhani had medium knowledge about agriculture, followed by 24.17 per cent with high and 17.50 with low knowledge about agriculture. The result shows that equal number $(35.00$ per cent) of the postgraduate scholars studying in VNMKV, Parbhani had medium as well as high level of knowledge about current issues followed by 30.00 per cent with low level of knowledge about current issues. It is observed that almost half (43.34 per cent) of the postgraduate scholars studying in VNMKV, Parbhani had high level of knowledge about Government policies on agriculture, followed by 30.83 per cent of the respondents with low level of knowledge and 25.83 per cent with medium level of knowledge about Government policies on agriculture and rural development. The results shows that more than half (67.50 per cent) of the postgraduate scholars studying in VNMKV, Parbhani had medium level of communication skills and 18.33 per cent of them had low level of communication skills. Rest 14.17 per cent had high level of communication skills. It is observed that more than half (60.83 per cent) of the postgraduate scholars studying in VNMKV, Parbhani had medium level of skills of using ICT tools followed by 23.33 per cent of them were with high level and 15.84 per cent with low level of skills of using the ICT tools. It is evident that more than half (55.83 per cent) of the postgraduate scholars studying in VNMKV, Parbhani perceived that they had high level of ability to face interviews, followed by 26.67 per cent of them were with medium and 17.50 per cent of them were with low level of ability to face the interviews.

The results show that more than majority (65.00 per cent) of the postgraduate scholars studying in VNMKV, Parbhani had perception that they possessed average level of selfconfidence, while 19.17 per cent of the postgraduate scholars had high self-confidence and the least i.e. 15.83 per cent of them had poor level of self-confidence. 
Table.1 Distribution of postgraduate scholars according to different indicators of employability

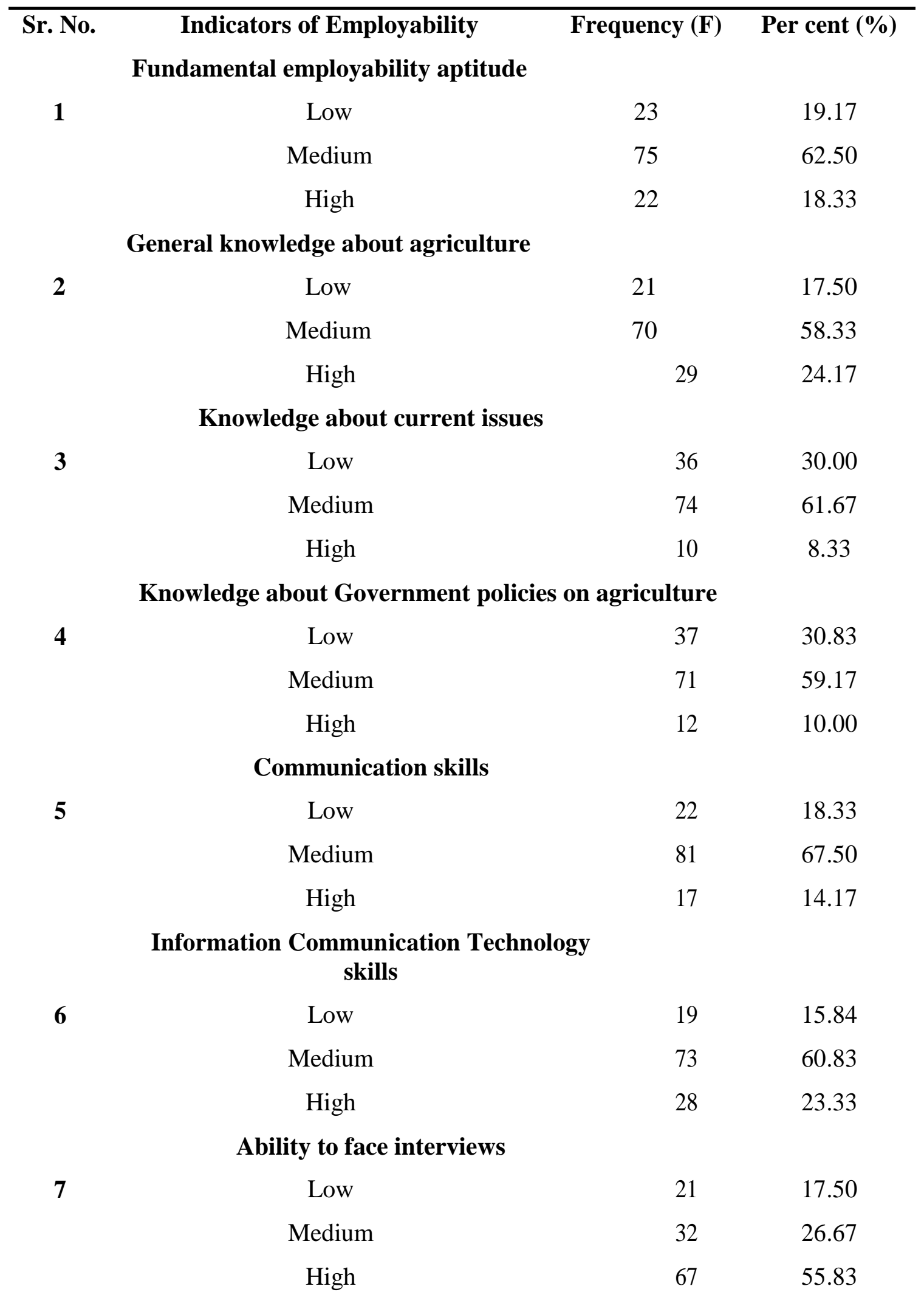




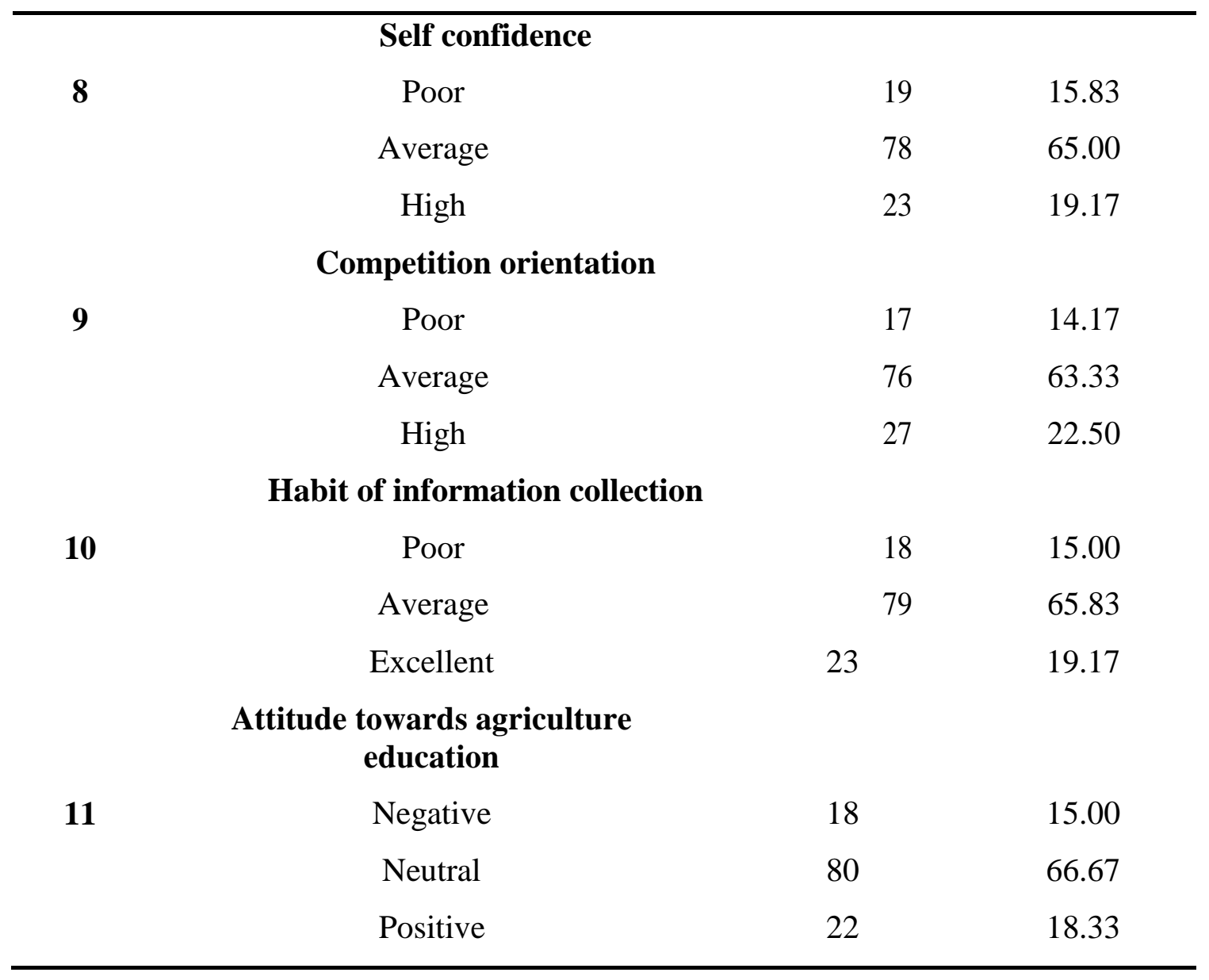

Table.2 Distribution of post graduate scholars according to their employability

\begin{tabular}{|c|c|c|c|}
\hline Sr. No. & Overall Employability & Frequency $(\mathbf{F})$ & Per cent (\%) \\
\hline 1 & Poor & 16 & 13.33 \\
\hline 2 & Average & 78 & 65.00 \\
\hline 3 & High & 26 & 21.67 \\
\hline
\end{tabular}

The results show that a majority $(63.33$ per cent) of the postgraduate scholars studying in higher agriculture education had average level of competition orientation, followed by 22.50 per cent of them with high level and rest 14.17 per cent of them were with poor level of competition orientation. It is found that majority (65.83 per cent) of the postgraduate scholars studying in higher agriculture education had average level habit of information collection, followed by 19.17 per cent of them with excellent habit of information collection and rest 15.00 of them were with poor habit of information collection. It is observed that more than half (66.67 per cent) of the postgraduate scholars studying VNMKV, Parbhani had neutral attitude towards agriculture education, followed by 18.33 per cent of them were with positive attitude and rest 15.00 per cent of 
were with negative attitude towards agriculture education. It is observed from Table 2 that a majority (65.00 per cent) of the postgraduate scholars studying VNMKV, Parbhani had average level of overall employability, followed by 21.67 per cent of them had high level of overall employability.

Overall employability was measured considering eleven different indicators. It is interesting to note that least number (13.33 per cent) of the postgraduate scholars studying VNMKV, Parbhani had poor level of overall employability. Thus it can be concluded that a great majority (86.67 per cent) of the postgraduate scholars associated with employability had average to high level of overall employability.

The result indicates that the postgraduate scholars have taken enough efforts to inculcate superior level of employability. The syllabuses of bachelor and master degrees in agriculture discipline have been developed in such a way that any agricultural graduates can work effectively in various fields. The degree programme and various integral parts of whole syllabus are such that they assist students to explore the awareness, understanding and skills among the students and develop confidence and competence for solving problems related to agriculture. Thus, entire academic programme and other additional courses like RAWE programme are framed in such a way that agricultural graduates can develop their career as academician, research scientist, extension educationist, progressive farmer, entrepreneur, business man, administrator, bank officer, forest officer and business managers.

Thus, activeness from the side of scholar, nature of syllabus and motivating academic, infrastructural facility, regional international level library facility, ICT availability and other favourable atmosphere created by authority, altogether might have played role for having average to high level of overall employability among majority of the postgraduate scholars studying in VNMKV, Parbhani.

\section{References}

Aher, A.N. (2010). Entrepreneurial attitude of agricultural students. M.Sc. (Agri.) Thesis (Unpub.), Anand Agricultural University, Anand.

Alston, A. J., Cromartie, D., Wakefield, D., \& English, C. W. (2009). The importance of employability skills as perceived by the employers of United States' landgrant college and university graduates. Journal of Southern Agricultural Education Research, 59(1), 59-72.

Anna, D. Rowe, Karsten E. Zegwaard (2017). Developing graduate employability skills and attributes: Curriculum enhancement through work-integrated learning. Asia-Pacific Journal of Cooperative Education, 18(2): 87-99.

Ariyawansa, R. G. (2008). Employability of graduates of Sri Lankan universities. Sri Lankan Journal of Human Resource Management, 1(2).

Chauhan, N.M. (2005). Construction of scale to measure computer anxiety/ nervousness. An assignment submitted to YCMOU, Nasik.

Christian, B.M. (2010). Computer proximity of women research scholars of SAUs of Gujarat. Ph.D. Thesis (Unpub.), Anand Agricultural University, Anand.

Hillage, J. and Pollard, E. (1998). Employability: Developing a framework for policy analysis. Research Brief 85, Department for Education and Employment, London.

Sasidharan, D. (2013). Employability of postgraduate scholars studying in higher agriculture education. M.Sc. (Agri.) Thesis (Unpublished). Anand 
Agricultural University, Anand.

Yorke, M. (2006). Employability in higher education: What it is and what it is not. The Higher Education Academy:
Learning and Employability Series No. 1. http://www.heacademy.ac.uk/ resources/publications/learningandemp loyabili ty accessed 21st July, 2014.

\section{How to cite this article:}

Pusparani Devi, Kh., J.V. Ekale, and Kulkarni, M.V. 2019. Employability of Post Graduate Scholars Studying in VNMKV, Parbhani, India. Int.J.Curr.Microbiol.App.Sci. 8(11): 22952301. doi: https://doi.org/10.20546/ijcmas.2019.811.266 